\title{
Abortion Due to Rape in The Perspective of Health Laws
}

\author{
Prihadi Gunawan \\ \{Prihadi.gunawan@gmail.com\} \\ Universitas Borobudur Jakarta, Indonesia
}

\begin{abstract}
This examination will talk about the issues identified with the philosophical establishment and the proportion legis that authorized the fetus removal because of assault, it's suggestions and the enactment strategy of early termination on account of pregnancy because of assault in Ius constituendum (future). This examination utilizes various methodologies included; Statute, Conceptual, and Historical Approaches. Regulatory approach in this assessment being used to break down the philosophical foundation and the extent legis in legitimizing to performing hatchling evacuation in view of attack. The exploration utilized the calculated and relative methodologies. Abortion on account of pregnancy because of assault have both physical and psychological well-being sway for the ones who has the early terminations. Consequently, the important enactment strategy with respect to the fetus removal on account of pregnancy because of assault ought to be defined by regard the legitimate conviction, handiness and decency as the target in established the law.
\end{abstract}

Keywords: Early termination; Rape; Health Law

\section{Introduction}

Wellbeing is a condition of wellbeing, regardless of whether actually, intellectually, profoundly or socially, which empowers everybody to live gainfully socially and financially. The right to wellbeing is a common freedom ensured by National Law and International Law. Subsequently, the right to prosperity is respected in the 1945 Constitution of the Republic of Indonesia, which guarantees every inhabitant to save the advantage to prosperity organizations. Article $28 \mathrm{H}$ of the 1945 Constitution communicates that, "Every individual has the advantage to dwell in physical and significant flourishing, to have a spot to live, and to have a respectable and sound living environment and the choice to secure prosperity organizations." with regards to carrying out Article $28 \mathrm{H}$ of the 1945 Constitution, the public authority supplanted the Health Law No.23 of 1992 which took on the worldview of ailment with Law No.36 of 2009 (hereinafter alluded to as the Health Law of 2009) which embraced the worldview. sound. With this healthy paradigm, the 2009 Health Law prioritizes preventive efforts by not neglecting curative efforts.

\section{Problem Statement}


This examination talks about "Fetus removal because of assault in a wellbeing law viewpoint," which expects to find the philosophical premise and lawful proportions of authorizing early termination because of assault in article 75 passage (2) of the Health Law. This concentrate likewise plans to track down the ramifications of legitimizing fetus removal because of assault, both juridical and non-juridical (clinical) ramifications and to endeavor to survey and reformulate enactment in regards to early termination because of assault later on (Ius Constituendum).

According to a hypothetical perspective, this exploration is relied upon to add to the improvement of speculations and ideas of wellbeing law and criminal law, especially in regards to the legitimization of early termination because of assault in the 2009 Health Law. Additionally, as information and simultaneously a suggestion in regards to enactment strategy on fetus removal because of assault later on. to come. As far as useful advantages, this examination is relied upon to give info and commitment to the chief and administrative bodies to audit the laws and guidelines identified with fetus removal because of assault. This examination is additionally expected to be helpful for specialists to be shrewder and more expert in dealing with early termination because of assault by focusing on the conditions that should be met for having a fetus removal. Cops who handle assault cases are relied upon to organize with specialists to forestall undesirable pregnancies just as taking care of ladies who are casualties of assault.

\section{Literature Review}

Article 75 paragraph (1) of the 2009 Health Law prohibits everyone from having an abortion, but provides exemptions for abortion on the basis of medical indications and abortion due to rape that results in psychological trauma. To decide the conditions for fetus removal because of assault that outcomes in mental injury, the 2009 Health Law requires a Government Regulation. The avoidance of early termination, particularly because of assault in the 2009 Health Law as a restricted demonstration, is in opposition to the fetus removal guidelines planned in the Criminal Code on the grounds that as of not long ago the Criminal Code thinks about fetus removal under any circumstance as a criminal demonstration.

\section{Research Method}

To answer the problem of abortion due to rape from a health law perspective, this study uses several approaches, namely the statutory approach (Statute Approach), the Conceptual Approach, and the Comparative Approach (Comparative Approach). The legal methodology is utilized to inspect the philosophical premise and consistent proportions for sanctioning early termination because of assault. The calculated methodology is utilized to inspect the ideas utilized in this concentrate like the idea of equity, the idea of common liberties, the fundamental idea of criminal nullification, the idea of criminal approach, and the idea of mental injury. The relative methodology utilized in this review is a miniature correlation with concentrate on the fetus removal laws of the Netherlands, Malaysia and Brazil.

\section{Discussion}


The philosophical reason of the Right to Health (Right to clinical benefits) is contained in Article $28 \mathrm{H}$ Paragraph (1) of the 1945 Constitution of the Republic of Indonesia, to be explicit "Everyone has the choice to live in physical and mental flourishing, to live, and to get a respectable and incredible living environment. strong and qualified for prosperity organizations. " Based on this article, everyone is guaranteed the choice to get prosperity organizations. Everybody for this situation is a lady who is pregnant, just as a hatchling in the belly, has the privilege to carry on with a sound life and get wellbeing administrations. Guaranteed right to health for women is the guarantee of their reproductive health rights. Guarantee the right to health in the fetus, has been guaranteed by law since the fetus was in the womb. This means that a pregnant woman is obliged to maintain the health of her fetus until she is born healthy and safe. This means that even though a woman has rights over her own body, from the moment of conception, she cannot determine whether she wants to continue or discontinue her pregnancy. The decision to continue or discontinue the pregnancy must be based on consideration of respect for the right to life of the fetus and consideration of the value of the soul to be sacrificed.

The Legis Ratio legitimizing early termination because of assault is to secure ladies' regenerative wellbeing, particularly for ladies who are pregnant because of assault. Considering Indonesian Demographic Survey Data, the Maternal Mortality Rate in Indonesia is still particularly high and most of the explanation is a direct result of unlawful embryo evacuation, most of which are unsafe early end. Besides, beginning around 1998 Indonesia has affirmed the International People Development Conference in Beijing. By turning into a member of the Conference, Indonesia should make decides in public enactment that ensure ladies' regenerative life and give ladies the opportunity to get pregnant or not to proceed with their pregnancies. In this manner, the Government's strategy to sanction early termination because of assault really doesn't give equity to the hatchling in the belly, in light of the fact that the embryo additionally has freedoms ensured by law to have the option to carry on with a solid life from the time it is in the belly.

The unique case for early end on account of attack as overseen in Article 75 entry (2) of the Health Law is clashing with Article $28 \mathrm{H}$ Paragraph (1) of the 1945 Constitution and Law No.36 of 2009 concerning Health, since fetus removal because of assault affects the actual wellbeing and emotional wellness of ladies. who have an early termination, it can even reason the culprit to lose his life? Not just that, early termination will likewise end the existence of an honest baby in the belly, and this is an infringement of the right to life of the embryo. Aside from the clinical ramifications, fetus removal because of assault will likewise have juridical ramifications since early termination because of assault must be legitimized if it satisfies the necessities specified in Article 75 Paragraph (2) and Article 76 of the 2009 Health Law jo. Unofficial law No.61 of 2014 concerning Reproductive Health. Assuming the conditions that have been set are not satisfied, the culprit will be dependent upon discipline as specified in Article 194 of the 2009 Health Law.

The prohibition of fetus removal because of assault in the 2009 Health Law, creates a norm conflict with the Criminal Code which prohibits abortion, but based on the principle of "Lex Specialis Derogat legi generalis," if there are general rules and special rules regulating the same or conflicting matters, then the rules More specifically, in this case what regulates specifically is the 2009 Health Law. The regulation on abortion due to rape in Article 75 paragraph (2) of the 2009 Health Law with strict restrictions aims to maintain morality values related to the right to life of the fetus, but it actually causes legal uncertainty, because the conditions for legalizing abortion are too complicated and unclear, and can even be abused by 
irresponsible people. In the RKUHP, the formulation of regulating abortion in the future still adopts the old rules, namely prohibiting and providing criminal threats to abortion perpetrators, but providing exceptions for abortion that is performed in an emergency as a certain medical measure to save pregnant women and / fetuses in the womb.

Essentially, the right to carry on with a sound life is a basic freedom, so it is fitting to consider sanctioning early termination because of assault, focusing on ladies' regenerative wellbeing privileges as well as the right to life of the baby in the belly. By thinking about these two rights, it implies that the public authority has satisfied the standards of equity, taking into account that dependent on Pancasila, equity implies a harmony among privileges and commitments. Each lady has the option to her own conceptive wellbeing; however, ladies additionally have the commitment to ensure their pregnancy until the baby is conceived solid and safe. Assault and pregnancy because of assault consistently effects affect ladies' wellbeing, both emotional wellness and actual wellbeing. Then again, fetus removal because of assault can likewise bring about the culprit being rebuffed if he doesn't satisfy the necessities specified in law. Thus, the Government needs to reevaluate the benefits and weaknesses of authorizing fetus removal because of assault, and reformulate the guideline of early termination because of assault as laid out in Article 75 passage (2) of Law No.36 of 2009 concerning Health. Reformulation should be done in light of the fact that the chance of executing Article 75 Paragraph (2) of the 2009 Health Law is undeniably challenging because of hazy conditions. Subsequently, for legitimate sureness, Article 75 Paragraph (2) in regards to the exemption of early termination because of assault ought to be eliminated from Law No.36 of 2009 concerning Health. Fully expecting the chance of fetus removal that imperils wellbeing (life), it is prescribed to utilize the reason for health-related crisis signs specified in Article 75 passage (2) or to utilize the reason for the end of violations as managed in Article 48 of the Criminal Code.

\section{Conclusion and Sugestion}

\subsection{Conclusion}

Wellbeing implies a condition when somebody actually, intellectually, profoundly and socially sound that made them every day routine a useful experience in friendly and monetary angle. The right of prosperity is a typical freedom that is guaranteed by worldwide and local law. Moreover, the right of prosperity determined under Indonesian constitution that guarantee every single Indonesian inhabitant to have the prosperity organization access as their right. The article $28 \mathrm{H}$ of Indonesia Constitution indicated that " Everybody hold the advantage to dwell genuinely and mentally princely, have a spot to stay, incredible and sound environment, and right to get to the prosperity organization."

Concerning executing article $28 \mathrm{H}$ of Indonesia constitution, state run organizations refreshed Law number 23 of 1992 that stressed to fix the inadequately changed it to give the preventive action under the law number 36 of 2009 overseeing Health. The new law will generally zero in on preventive action without overlooks the mending measure. Article 75 segment (1) restricts anybody to perform early termination, but it likewise gives exemptions for carry on fetus removal under clinical signs and fetus removal if there should be an occurrence of pregnancy because of assault that led to clinician injury. The restriction of early end in light of attack under Health law is contrary to the rule that described under the Criminal 
Code that hatchling evacuation regardless is an unlawful action. To choose the awful conditions, law number 36 of 2009 requires informal law that was not overseen under the law.

This composition will discuss "Early end in view of attack in the Perspective of Health Law." It is intended to find the Philosophical establishment and the extent legis that legitimized baby expulsion due to attack determined in article 75 region (2) of the Health Law. This examination additionally having direction to track down the ramifications in authorizing fetus removal because of assault, both juridical ramifications and non-juridical ramifications (clinical). It additionally attempts to examine and figure enactment strategy that direct fetus removal because of assault later on (Ius constituendum). The advantages of this examination can be checked on from of hypothetical and viable viewpoints. Concerning theory, this assessment expected to give the obligation to the improvement of hypotheses through the thoughts of prosperity law and criminal law, particularly related to the authorizing of hatchling expulsion in light of attack under Law number 36 of 2009 on Health Law and as data and moreover related methodology ideas due to early end establishment attack later on. Practical benefits of this assessment are depended upon to give thoughts and obligation to the boss and the lawmaking body to review the law related to the embryo expulsion due to attack base on the juridical repercussions set up in this investigation. This concentrate moreover expected to be the course for clinical experts while dealing with the early end in light of attack to be more prudent and master in fulfilling the arrangements that should be met to lead a hatchling expulsion. It is depended upon to be a heading for the cops who handle the attack case to manufacture a better coordination with clinical experts than thwart unwanted pregnancies similarly as preventing early end for women setbacks of attack.

\subsection{Suggestion}

To resolve the issues of fetus removal because of assault in the viewpoint of wellbeing law, this examination utilizes various methodologies those are; Statute Approach, Conceptual Approach, and Historical Approach. Authoritative methodology used to analyze the philosophical foundation and proportion legis that sanctioned the fetus removal because of assault. The theoretical methodology in this examination is utilized to analyze a few existed; the idea of equity, the of common freedoms idea, the fundamental idea of the cancelation of the lawbreaker, correctional arrangement idea, and the idea of injury clinician. The relative methodology in this exploration utilized to evaluate the near miniature fetus removal enactment from the Netherlands, Malaysia and Brazil.

Article 28 H Section (1) of the Indonesian Constitution of 1945 indicated; "Everyone has the advantage to reside really and significantly achievement, has the choice to home, and has the choice to get a respectable and strong dwelling environment, and right to prosperity organizations." In solicitation to meet general society's proper for the prosperity, the public authority set up the Law number 36 of 2009 on Health which has the novel thought that is preventing the infection. Taking into account the constitution, each person in this matter is a pregnant woman, similarly as the child in the paunch the two has the choice to live and the right in prosperity organizations access. The extent legis that approve the early end as a result of attack is to guarantee the women's regenerative prosperity, especially for the loss of the attack who are pregnant. This idea subject to the Indonesian Population Demographic Data Survey, where the maternal passing rate in Indonesia unbelievably high, and by far most of the makes is normal the illegal embryo expulsions which generally risky early end. Besides, starting around 1998, Indonesia has authorized the International Convention of People and Development in Beijing. Being one of the individuals from the gathering, Indonesia obliged to 
convey the rule that guarantee the female regenerative life and offer them the chance to consider or not to continue with the pregnancy.

The extraordinary instance of early end on account of attack as indicated in article 75 fragment (2) of the Health Law is conflicted with the rule under Article $28 \mathrm{~h}$ region (1) of the Indonesian Constitution and the previous prosperity Law number 23 of 2002 on Health. The early end in light of attack has real prosperity influence, similarly as mental health influence for the loss who drop the pregnancy, and shockingly in a couple of cases could close with death as the impact of hazardous baby evacuation. Early end similarly kills the presences of guiltless child in the paunch of the woman which also builds up an encroachment of the right to life of the incipient organism. Regardless the clinical consequences, the early end in light of attack also lead to juridical repercussions of embryo evacuation that should be approved if it meets the requirements determined in Article 75 Section (2) and Article 76 of the Health Law of 2009 identified with The Government Regulation number 61 of 2014 on Reproduction Health. If the conditions that has been set up doesn't fulfilled, the lowlife will be blamed for the criminal offenses implied in Article 192 of the Health Law. Early end related authorization methodology was at first coordinated under the law number 1 of 1946 on Criminal Code identified with Law number 73 of 1958, known as the Penal Code. The reformatory code prohibits anyone to play out the early terminations with essentially no exclusions. Prohibiting hatchling evacuation regardless, is seen as disharmonies with the early terminations performed by clinical experts to save the presences of pregnant women. In this way, the public authority authorized the Law number 23 of 1992 on Health, which in Article 15 Section (1) determined that "if there ought to emerge an event of wellbeing related emergency, as a work to save a pregnant mother or potentially child ought to be conceivable a particular activity."

The current Health Law remains refuses to passes on early end. Regardless, it gives the exclusions for play out the early end by virtue of pregnancy on account of attack that has caused outrageous mental injury for the individual being referred to. Those necessities controlled under the prosperity law transformed into an obstacle that is jumbled and as the aftereffect of the foggy rule, especially to meet the condition of "specialist genuine injury", since there is no standard that could choose the requirements of how outrageous mental injury when every individual has the particular tirelessness to adjust the issues. Early end related establishment technique later on at this point accepting the principles in the current Criminal Code, by adding one region that took on from Article 15 of Health Law of 1992. The Criminal Code Draft also expanded attack that is controlled in article 285 of the Criminal Code, thusly the arrangement of hatchling expulsion by virtue of pregnancy on account of attack should similarly be changed as per the groundbreaking thought that could restrict multi understandings as the result of jumbled rule.

Essentially, the right to wellbeing is a basic freedom, hence it is normal to consider authorizing the early termination on account of pregnancy because of assault that not just focusing on the regenerative wellbeing as the privileges of ladies, yet additionally the right to life claimed by the baby in their belly. Considering, both of that correct method the public authority needs to satisfied the standards of equity, which depends on "Pancasila". Equity implies a harmony among freedoms and commitments when every lady has the privilege to their own regenerative wellbeing, yet they additionally have the commitment to keep up with the pregnancy until the hatchling brought into the world in a solid and safe condition. Assault and pregnancy because of assault continually cause adverse consequences against ladies' wellbeing both psychological wellnesses just as actual wellbeing, and even lead to of fetus removal because of assault entertainers rebuffed in the event that it doesn't meet the necessities determined Law. Later on, Government needs to survey of the benefits and 
impediments of authorizing the early termination because of assault and reformulate the arrangements of fetus removal because of assault that been gone ahead under Article 75 segment (2) of Health Law. Reformulation is fundamentally planned to explain the necessities that must be satisfied to play out the fetus removals. Despite the fact that the public authority needs as far as possible the conditions to perform fetus removal, these principles ought to be planned cautiously and as unmistakably as could really be expected, subsequently staying away from multi understanding and give legitimate conviction to general society.

\section{References}

[1] Constitution of the Republic of Indonesia year 1945

[2] Law No. 1 of 1946 concerning The Regulation of Criminal Law Jo Law No. 73 of 1958 concerning the Enactment of the Criminal Code for All Regions of Indonesia.

[3] Law No. 4/1979 on Child Welfare (Statute Book of 1979 No. 32, Supplement to Statute Book No. 3143).

[4] Law No. 4 of 1984 on Ratification of the Convention on the Elimination of All Forms of Discrimination Against Women (CEDAW)

[5] Law No. 23/1992 on Health (Statute Book of 1992, No. 100 Supplement to Statute Book No. 3495).

[6] Law No. 39/1999 on Human Rights (Statute Book of the Republic of Indonesia of 1999, No. 165 Supplement to Statute Book No. 4206).

[7] Law No. 26/2000 on Human Rights Court (Statute Book of 2000, No. 208 Supplement to Statute Book No. 4026.

[8] Law No. 25/2004 on National Development Planning System (State Gazette of the Republic of Indonesia of 2004, Number 150, Supplement to Statute Book No. 4456).

[9] Law No.11 of 2005 on ratification of the International Covenant on Economic, Social, and Culture Rights (ICESC).

[10] Law No.12 of 2005 on ratification of the International Covenant on Civil and Political Rights (ICCPR).

[11] Law No. 36/2009 on Health (Statute Book of the Republic of Indonesia of 2009 No. 1441, Supplement to Statute Book No. 5063).

[12] Law No. 12/2011 on the Establishment of Laws and Regulations (Statute Book of 2011, No. 82, Supplement to Statute Book No. 5234).

[13] Law No. 35 of 2014 on Amendments to Law No.23 of 2002 on Child Protection (Statute Book of the Republic of Indonesia)

[14] Year 2014, Number 297 Supplement to Statute Book no. 5606 of 2014.

[15] Government Regulation No. 61/2014 on Reproductive Health (Statute Book of 2014, No. 169, Supplement to Statute Book of 2014 No. 5559).

[16] Presidential Decree No.36 of 1990 on ratification of the Convention on The Rights of The Children.

[17] Decree of the Minister of Health No. 131/MENKES/SK/II/2004 concerning the National Health System.

[18] Decree of the Minister of Health No. 1202 /MENKES/SK/VII/2003 concerning Healthy Indonesia Indicators 2010 and Guidelines for Determining Indicators of Healthy Provinces and Healthy Districts 


\section{List of Abbreviations}

AKI

AKB

RISKESDAS

JAMPERSAL

SDKI

PKKP

BKKBN

UU KESEHATAN

DEPKES

HAM

DUHAM

ICCPR

ICESR

MVT

PTSD

PAS

WHO
: Angka Kematian Ibu (Maternal Mortality Rate)

: Angka Kematian Bayi (Infant Mortality Rate)

: Riset kesehatan Dasar (Basic health research)

: Jaminan Persalinan (Maternity Guarantee)

: Survey Dasar Kesehatan Indonesia (Basic Health Survey of Indonesia)

: Pusat Kajian Kesehatan Perempuan (Center for Women's Health Studies)

: Badan Kependudukan dan Keluarga Berencana Nasional (National Population and Family Planning Agency)

: Undang-Undang Kesehatan (Health Law)

: Departemen kesehatan (Department of Health)

: Hak Asasi Manusia (Human Rights)

: Deklarasi Universal Hak Asasi Manusia (Universal Declaration of Human Rights)

: International Covenan on Civil and Political Right

: International Covenan on Economic, Social and Cultural Right

: Memorie van Toelichting

: Post Traumatic Sindrome Disease

: Post Abortion Sindrome

: World Health Organization 